\title{
Green Initiatives and its Outcome in Higher Education Institutions in Erode District
}

\author{
V. Renugadevi* \\ Assistant Professor, PG and Research Department of Commerce, Vellalar College for Women (Autonomous), \\ Erode,Tamil Nadu, India; vrenuvcw@gmail.com
}

\begin{abstract}
Techno economic growth without planning leads to deterioration of environment and depletion of natural resources. Degradation of natural resources causes damage to ozone shield which raises the concentration of carbon dioxide in the atmosphere. It causes many chain link effects. Knowledge on environment is the need of the hour and it is necessary to create awareness among the public especially among younger generation. Reuse and Recycling of waste water, creating environment awareness, effective utilization of natural resources and public education are the basic needs which help to protect the environment. Environment education is the effective remedy to solve the problem and it is mandatory for the educational institutions to incorporate environment education in their syllabi. Moreover, green concept, environment audit are also to be introduced in the campus. In this backdrop, the present study deals with the possibilities of implementing green campus concept and benefits achieved from such implementation in higher educational institutions. A sample of fourteen out of seventeen arts and science colleges situated in Erode district were selected for the present study, excluding three colleges which were found to be in infant stage. Factor analysis was used to identify the most beneficial factor enjoyed by the institutions. Principal Component Analysis method was also applied to extract the major factors by Vari Max rotation. The variables identified are the key factors which can be concentrated on more by the educational institutions to save the environment.
\end{abstract}

Keywords: Depletion, Environment Audit, Environment Education, Green Concept, Natural Resources

\section{Introduction}

A natural environment is essential for healthy living. But environment is degraded day by day due to the pollution caused by human activity. Enormous use and over exploitation of natural resources threaten the existence of entire life in the planet. The atmosphere is totally deteriorated which causes global warming and these changes are expected to make human life more miserable in the times to come. There is a serious lack of awareness of the environmental problems among our citizens of both illiterates and so-called intelligentsia. The absence of any environmental education in the curricula of schools, colleges and universities in majority of the states has contributed to such massive ignorance of the issues related to the environment; its necessity to human life and its protection from hazards.
The study of ecology is not to be treated as a luxury but necessary for our very existence on the earth. The temper and culture of science of environment should be generated at the rural and urban levels. In achieving this objective, the government agencies, the professional societies and academics can play a prominent role ${ }^{1}$.

Preserving the environment for the future generation is the pressing activity all over the world. The energy policy of India is largely defined by the country's burgeoning energy deficit and increased focus on developing alternative sources of energy, particularly nuclear, solar and wind energy. Hence, Energy Conservation has emerged a major policy objective, and according to the Energy Conservation Act 2001, large energy consumers need to adhere to energy consumption norms; new buildings to follow the energy conservation building code; and appliances to meet energy

${ }^{*}$ Author for correspondence 
performance standards and to display energy consumption labels ${ }^{2}$. Creating environmental awareness among the youth is the good remedy for the problem. At present, all higher education institutions have introduced environmental awareness subject and programs in the syllabi to ensure that the students are environmentally educated and aware of the daily practices in creating a sustainable community.

Amit Maheshwari ${ }^{3}$, Director, Marketing and Strategy, Carrier India, opines that though Green Consumer Day is observed on September 28, globally, as responsible Indian citizens, it should be celebrated on a day basis to throw light on the positives associated with sustainability.

To protect the environment, green initiative measures are taken at college level. It not only protects environment but also creates awareness among younger generation and the public in and around the college campus. Implementing and taking steps for green initiative strategy is not an easy task. The colleges have to plan well in advance about the activities to be taken at college campus, at student level and at general public level. Green campus strategy may appear expensive initially, but in the long-run cost savings will be achieved if select initiatives are implemented properly. An investigation regarding the benefits of green initiative measures adopted in the higher education institutions will help for the environmental sustainability.

\section{Review of Literature}

Glenn A. Cummings ${ }^{4}$ exposed that the environmental concerns in teaching and learning, research and development and in the on-campus modeling are the factors that help to solve the environment problems and suggested that leadership can employ these strategies to overcome obstacles and create significant institutional achievement in the area of sustainability. Michael D'Alimonte ${ }^{5}$ found that students engaged in green practices have an increased interest in science and math-based subjects and also they are more involved in extracurricular environmental projects. Shweta Aggarwal and Utkarsh Jaiswal ${ }^{6}$ in their study have exposed the 'green computing practices', which leads to using computing resources efficiently. Chieh-Yu Lin and Yi-Hui $\mathrm{Ho}^{7}$ in their research focused on the determinants of green practice infusion in various firms. Vernekar S. S and Venkatasubramanian $\mathrm{K}^{8}$ in their research suggested that the developing countries need to retrieve the old practices which are eco-friendly and even challenge the western technology, driven by multinationals for profits.

However, the present study focuses on the implementation of green initiative measures and the positive outcomes reaped among higher educational institutions of arts and science.

\section{Objectives of the Study}

- To assess the existing green initiative measures implemented among the sample colleges.

- To identify the factors determining the positive outcomes of green initiative measures adopted by the higher education institutions for environmental sustainability.

\section{Methodology}

The study is based on primary data collected through a structured questionnaire. Secondary data has also been tapped from websites, books, leading journals and magazines. Population of the study comprises arts and science colleges situated in Erode District. There are totally 17 such colleges in the district and the questionnaire has been administered to these colleges for collecting the data. However out of 17 colleges 3 are in infant stage which could not respond to the questionnaire completely. Hence, the study is based on the remaining 14 arts and science colleges constituting the total sample. Simple percentage has been employed to assess the existing green initiative measures among the sample colleges. The various benefits reaped by the sample colleges on unleashing green practices in their campus has been identified through a vast range of ten statements with a three point scale (Not at all, To some extent, To a great extent), which include i) Lower operations and maintenance cost; ii) Improved electricity quality and reliability; iii) Reduced insurance and risk related cost; iv) Improved educational quality; v) Reduced natural resources consumption; vi) Reduced waste; vii) Reduced pollutant emission; viii) Improved environmental and financial performance; ix) Greater responsiveness to social and environmental expectation; and $\mathrm{x}$ ) Enhanced social, human and knowledge capital. Factor Analysis has enabled to condense these into a simplified version of underlying related factors.

\section{Data Analysis and Interpretation}

\subsection{Assessment of Existing Green Initiative Measures}

The existing green initiative measures among the sample colleges have been assessed by simple percentage technique on the following parameters:

- Students' Enrollment in Green Society of the College.

- Efficient Resource Utilisation in Maintaining the Campus Garden. 
- Energy Saving Lighting Facilities.

- Eco- Friendly Methods to Treat Waste.

- Reduction of Carbon Emission in the Campus.

- Reduction of Water Consumption in the Campus.

- Adoption of Sustainable Purchasing Policy.

- Adoption of Green Building Practices.

- Promotion of Fresh Food Habits.

- Greening Efforts.

Table 1. Students' enrollment in green society of the college

\begin{tabular}{llll}
\hline S. No. & $\begin{array}{l}\text { Students' } \\
\text { Enrollment }\end{array}$ & $\begin{array}{l}\text { No. of } \\
\text { Colleges }\end{array}$ & Percentage \\
\hline 1. & $\begin{array}{l}\text { Less than } 100 \\
\text { students }\end{array}$ & 5 & 36 \\
2. & $\begin{array}{l}\text { 100-200 students } \\
\text { 3. }\end{array}$ & 8 & 57 \\
& $\begin{array}{l}\text { More than } 200 \\
\text { students }\end{array}$ & 1 & 7 \\
& Total & 14 & 100
\end{tabular}

\section{Source: Primary data}

On the score of 'Students' Enrollment in Green Society of the College', Table 1 reveals that a majority of $57 \%$ of the sample colleges have enrolled 100-200 students in Green Society of the College.

Table 2. Efficient resource utilisation in maintaining the campus garden

\begin{tabular}{llll}
\hline $\begin{array}{l}\text { S. } \\
\text { No. }\end{array}$ & Facilities & $\begin{array}{l}\text { No. of } \\
\text { Colleges }\end{array}$ & Percentage \\
\hline 1. & Sewage treatment plant & 6 & 43 \\
2. & Recycling of waste water & 5 & 36 \\
3. & Organic farming & 10 & 71 \\
4. & Drip irrigation & 6 & 43 \\
5. & Rain water harvesting & 14 & 100 \\
$6 . \quad \begin{array}{l}\text { Landscaping with grass, } \\
\text { ornamental plants and } \\
\text { shady trees }\end{array}$ & 14 & 100 \\
\hline
\end{tabular}

\section{Source: Primary data}

On the score of 'Efficient Resource Utilisation in Maintaining the Campus Garden', Table 2 shows that all the sample colleges have implemented rain water harvesting and their landscaping comprises grass, ornamental plants and shady trees. However, recycling of waste water is implemented by $36 \%$ of the sample colleges only.
Table 3. Energy saving lighting facilities

\begin{tabular}{|c|c|c|c|}
\hline $\begin{array}{l}\text { S. } \\
\text { No. }\end{array}$ & Devices & $\begin{array}{l}\text { No. of } \\
\text { Colleges }\end{array}$ & Percentage \\
\hline 1. & Solar light & 6 & 43 \\
\hline 2. & $\begin{array}{l}\text { Compact Fluorescent } \\
\text { Lamp (CFL) }\end{array}$ & 13 & 93 \\
\hline 3. & $\begin{array}{l}\text { Light Emitting } \\
\text { Diode(LED) lighting }\end{array}$ & 5 & 36 \\
\hline 4. & $\begin{array}{l}\text { Light sensor for } \\
\text { lighting control }\end{array}$ & 1 & 7 \\
\hline 5. & $\begin{array}{l}\text { Daylight dimming } \\
\text { control }\end{array}$ & 1 & 7 \\
\hline 6. & $\begin{array}{l}\text { Skylights in the } \\
\text { cafeteria and } \\
\text { gymnasium }\end{array}$ & 9 & 64 \\
\hline
\end{tabular}

\section{Source: Primary data}

On the score of 'Energy Saving Lighting Facilities', Table 3 discloses that $93 \%$ of the sample colleges have CFL lighting facility, $64 \%$ have skylights in the cafeteria and gymnasium, $43 \%$ have solar lights and 36\% have LED lights.

Table 4. Eco-friendly methods to treat waste

\begin{tabular}{llll}
\hline $\begin{array}{l}\text { S. } \\
\text { No. }\end{array}$ & Eco-Friendly Practices & $\begin{array}{l}\text { No. of } \\
\text { Colleges }\end{array}$ & Percentage \\
\hline 1. & $\begin{array}{l}\text { Preparing organic } \\
\text { manure }\end{array}$ & 6 & 43 \\
2. $\quad \begin{array}{l}\text { Installation of } \\
\text { incinerators }\end{array}$ & 3 & 21 \\
3. $\quad \begin{array}{l}\text { Policy of serving food } \\
\text { items based on the } \\
\text { orders to avoid waste }\end{array}$ & 5 & 36 \\
4. $\quad \begin{array}{l}\text { Recycled papers in } \\
\text { classrooms and office }\end{array}$ & 5 & 36 \\
5. $\quad \begin{array}{l}\text { Organic food waste used } \\
\text { for composting in worm } \\
\text { bin }\end{array}$ & 4 & 29 \\
6. $\quad \begin{array}{l}\text { Discourage the use of } \\
\text { disposable plastic bottles }\end{array}$ & 10 & 71 \\
7. $\quad \begin{array}{l}\text { Reuse of papers printed } \\
\text { on one side }\end{array}$ & 13 & 93 \\
\hline
\end{tabular}

\section{Source: Primary data}

On the score of 'Eco-friendly Methods to Treat Waste', Table 4 brings to the fore that $93 \%$ of the sample colleges reuse the papers printed on one side, $71 \%$ of them discourage the use of disposable plastic bottles, $43 \%$ of them prepare organic manure and $36 \%$ of them follow the policy of serving food items based on the orders to avoid waste and as well use the recycled papers in classrooms and office. 
Table 5. Reduction of carbon emission in the campus

\begin{tabular}{|c|c|c|c|}
\hline $\begin{array}{l}\text { S. } \\
\text { No. }\end{array}$ & Practices & $\begin{array}{l}\text { No. of } \\
\text { Colleges }\end{array}$ & Percentage \\
\hline 1. & $\begin{array}{l}\text { Switched over to CFL } \\
\text { or LED light bulbs }\end{array}$ & 12 & 86 \\
\hline 2. & Conduct energy audit & 7 & 50 \\
\hline 3. & $\begin{array}{l}\text { Purchased energy } \\
\text { efficient appliances or } \\
\text { equipments }\end{array}$ & 10 & 73 \\
\hline 4. & $\begin{array}{l}\text { Installed solar } \\
\text { photovoltaic (PV) } \\
\text { panels }\end{array}$ & 7 & 50 \\
\hline 5. & Installed solar hot water & 7 & 50 \\
\hline 6. & $\begin{array}{l}\text { Implemented 'turn it } \\
\text { off' campaign }\end{array}$ & 5 & 36 \\
\hline 7. & $\begin{array}{l}\text { Prohibited smoking } \\
\text { in the campus and in } \\
\text { college buses }\end{array}$ & 14 & 100 \\
\hline
\end{tabular}

\section{Source: Primary data}

On the score of 'Reduction of Carbon Emission in the Campus', Table 5 exhibits that all the sample colleges have prohibited smoking in the campus and in college buses, $86 \%$ of them have switched over to CFL or LED light bulbs, $73 \%$ of them have purchased energy efficient appliances or equipments and $50 \%$ of them have conducted energy audit, installed solar Photovoltaic (PV) panels and also solar hot water.

Table 6. Reduction of water consumption in the campus

\begin{tabular}{|c|c|c|c|}
\hline $\begin{array}{l}\text { S. } \\
\text { No. }\end{array}$ & Practices & $\begin{array}{l}\text { No. of } \\
\text { Colleges }\end{array}$ & Percentage \\
\hline 1. & $\begin{array}{l}\text { Installed automatic } \\
\text { regular flow of water }\end{array}$ & 3 & 21 \\
\hline 2. & $\begin{array}{l}\text { Periodic check for water } \\
\text { leaks }\end{array}$ & 13 & 93 \\
\hline 3. & $\begin{array}{l}\text { Installed drip and timed } \\
\text { irrigation systems for } \\
\text { landscaping }\end{array}$ & 12 & 86 \\
\hline 4. & $\begin{array}{l}\text { Maintain working } \\
\text { drinking water fountains }\end{array}$ & 14 & 100 \\
\hline 5. & $\begin{array}{l}\text { Control water runoff } \\
\text { with rain barrels or rain } \\
\text { gardens }\end{array}$ & 3 & 21 \\
\hline
\end{tabular}

\section{Source: Primary data}

On the score of 'Reduction of Water Consumption in the Campus', it can be inferred from Table 6 that all the sample colleges maintain working drinking water fountains, $93 \%$ of them carryout periodic check for water leaks and $86 \%$ of them have installed drip and timed irrigation systems for landscaping.

Table 7. Adoption of sustainable purchasing policy

\begin{tabular}{llll}
\hline $\begin{array}{l}\text { S. } \\
\text { No. }\end{array}$ & Sustainable Policies & $\begin{array}{l}\text { No. of } \\
\text { Colleges }\end{array}$ & Percentage \\
\hline 1. & $\begin{array}{l}\text { Purchased paper } \\
\text { requirements with } \\
\text { recycled content }\end{array}$ & 14 & 100 \\
2. $\quad \begin{array}{l}\text { Purchased college supplies } \\
\text { like notebooks, folders } \\
\text { with recycled content }\end{array}$ & 14 & 100 \\
& $\begin{array}{l}\text { Purchased computers, } \\
\text { appliances, equipments } \\
\text { with energy star rating }\end{array}$ & 12 & 86 \\
3. Purchased furniture with & 4 & 29 \\
recycled content & $\begin{array}{l}\text { Purchased rechargeable } \\
\text { batteries }\end{array}$ & 10 & 71 \\
5. & & \\
\hline
\end{tabular}

\section{Source: Primary data}

On the score of 'Adoption of Sustainable Purchasing Policy', Table 7 confirms that all the sample colleges have adopted the policy of procuring recycled papers, notebooks and folders with recycled content and $86 \%$ of them purchase computers, appliances, and equipments with energy star rating.

Table 8. Adoption of green building practices

\begin{tabular}{|c|c|c|c|}
\hline $\begin{array}{l}\text { S. } \\
\text { No. }\end{array}$ & Practices & $\begin{array}{l}\text { No. of } \\
\text { Colleges }\end{array}$ & Percentage \\
\hline 1. & $\begin{array}{l}\text { Adequate air circulation } \\
\text { with lighting efficiency }\end{array}$ & 14 & 100 \\
\hline 2. & $\begin{array}{l}\text { Maintenance of natural } \\
\text { grass field }\end{array}$ & 7 & 50 \\
\hline 3. & $\begin{array}{l}\text { Growing trees and edible } \\
\text { plants in the garden }\end{array}$ & 10 & 71 \\
\hline 4. & $\begin{array}{l}\text { Out-door seatings } \\
\text { around the garden }\end{array}$ & 14 & 100 \\
\hline 5. & $\begin{array}{l}\text { Safety measures in the } \\
\text { playground }\end{array}$ & 14 & 100 \\
\hline 6. & $\begin{array}{l}\text { Chosen low-emitting } \\
\text { paints, carpets, } \\
\text { whiteboard markers, } \\
\text { art supplies or other } \\
\text { materials to improve } \\
\text { indoor air quality }\end{array}$ & 7 & 50 \\
\hline 7. & $\begin{array}{l}\text { Provision for adequate } \\
\text { ventilation in rooms }\end{array}$ & 14 & 100 \\
\hline
\end{tabular}

\section{Source: Primary data}


On the score of 'Adoption of Green Building Practices', Table 8 indicates that all the sample colleges have provided for adequate air circulation with lighting efficiency, outdoor seatings around the garden, adequate ventilation in rooms and safety measures in the playground.

Table 9. Promotion of fresh food habits

\begin{tabular}{llll}
\hline $\begin{array}{l}\text { S. } \\
\text { No. }\end{array}$ & Practices & $\begin{array}{l}\text { No. of } \\
\text { Colleges }\end{array}$ & Percentage \\
\hline 1. & $\begin{array}{l}\text { Offering organic food } \\
\text { at lunch }\end{array}$ & 6 & 43 \\
2. & $\begin{array}{l}\text { Banned soda and } \\
\text { candy vending at } \\
\text { college }\end{array}$ & 12 & 86 \\
& $\begin{array}{l}\text { Availability of 'Aavin' } \\
\text { products for sale }\end{array}$ & 3 & 21 \\
\hline
\end{tabular}

\section{Source: Primary data}

On the score of 'Promotion of Fresh Food Habits', Table 9 exposes that as high as $86 \%$ of the sample colleges have banned the sale of soda and candies, while $43 \%$ of them offer organic food at lunch and $21 \%$ of them offer 'Aavin' products.

Table 10. Greening efforts

\begin{tabular}{|c|c|c|c|}
\hline S. No. & Practices & $\begin{array}{l}\text { No. of } \\
\text { Colleges }\end{array}$ & Percentage \\
\hline 1. & $\begin{array}{l}\text { Teaching } \\
\text { environmental } \\
\text { education }\end{array}$ & 14 & 100 \\
\hline 2. & $\begin{array}{l}\text { Environmental and } \\
\text { sustainability concepts } \\
\text { are integrated into } \\
\text { student assessments }\end{array}$ & 8 & 57 \\
\hline 3. & $\begin{array}{l}\text { Offer outdoor and } \\
\text { field trips to hone } \\
\text { environmental } \\
\text { consciousness }\end{array}$ & 8 & 57 \\
\hline 4. & $\begin{array}{l}\text { Use college garden for } \\
\text { education }\end{array}$ & 10 & 71 \\
\hline 5. & $\begin{array}{l}\text { Undertake hands-on } \\
\text { environmental projects }\end{array}$ & 4 & 29 \\
\hline 6. & $\begin{array}{l}\text { Involve students in } \\
\text { solving environmental } \\
\text { problems by clean } \\
\text { ambiance and garbage } \\
\text { maintenance }\end{array}$ & 8 & 57 \\
\hline 7. & $\begin{array}{l}\text { Leadership positions } \\
\text { to student members } \\
\text { enrolled in Green } \\
\text { Society of the college }\end{array}$ & 14 & 100 \\
\hline
\end{tabular}
8.
Carryout environmental audit of 7 college resources

\section{Source: Primary data}

On the score of 'Greening Efforts', it can be perceived from Table 10 that all the sample colleges involve in teaching environmental education and offer leadership positions to student members enrolled in Green Society, $71 \%$ of them use their garden for educating students on medicinal value and the general environmental value of various plants and trees, $57 \%$ of the colleges have integrated environmental and sustainability concepts into student assessments; involve students in solving environmental problems by clean ambiance and garbage maintenance; and offer outdoor and field trips to hone environmental consciousness.

\subsection{Factors Determining the Positive Outcome of Green Initiative Measures}

To highlight the factors determining the positive outcome of green initiative measures adopted by the sample colleges, Factor Analysis has been employed. The collected data is tabulated and analyzed by using a Multi-variate statistical technique- Exploratory Factor Analysis and the major factors are identified and the results are shown in Tables 11-14.

Table 11. KMO and Bartlett's test

\begin{tabular}{|c|c|c|}
\hline \multicolumn{2}{|c|}{$\begin{array}{l}\text { Kaiser- Meyer- Olkin measure of sampling } \\
\text { Adequacy }\end{array}$} & \multirow{2}{*}{$\begin{array}{l}0.562 \\
65.311\end{array}$} \\
\hline \multirow{3}{*}{$\begin{array}{l}\text { Bartlett's Test of } \\
\text { Sphericity }\end{array}$} & Approx.Chi- square & \\
\hline & d.f & 0.45 \\
\hline & Sig & 0.025 \\
\hline
\end{tabular}

Source: Primary data

The KMO index of not less than 0.50 validates the employment of factor analysis. ${ }^{9-11}$ Table 11 reveals that the Kasier-Mayor-Olkin (KMO) Measure of sampling adequacy in the study is 0.562 , which therefore justifies and confirms that further study can be carried on.

\subsubsection{Total Variance Explained}

Table 12 depicts the Total Variance Explained which includes various components like Initial Eigen values, Extraction sums of squares of loadings and Rotation sums of squared loadings. 
Table 12. Total variance explained

\begin{tabular}{|c|c|c|c|c|c|c|c|c|c|}
\hline \multirow{2}{*}{ 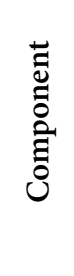 } & \multicolumn{3}{|c|}{ Initial Eigen Values } & \multicolumn{3}{|c|}{ Extraction Sum of Squared } & \multicolumn{3}{|c|}{$\begin{array}{l}\text { Rotation Sums of } \\
\text { Loadings }\end{array}$} \\
\hline & Total & $\begin{array}{c}\% \text { of } \\
\text { Variance }\end{array}$ & $\begin{array}{c}\text { Cumulative } \\
\%\end{array}$ & Total & $\begin{array}{c}\% \text { of } \\
\text { Variance }\end{array}$ & $\begin{array}{c}\text { Cumulative } \\
\%\end{array}$ & Total & $\begin{array}{c}\% \text { of } \\
\text { Variance }\end{array}$ & $\begin{array}{c}\text { Cumulative } \\
\%\end{array}$ \\
\hline 1. & 3.808 & 38.076 & 38.076 & 3.808 & 38.076 & 38.076 & 3.387 & 33.868 & 33.868 \\
\hline 2. & 2.581 & 25.810 & 63.886 & 2.581 & 25.886 & 63.886 & 3.002 & 30.019 & 63.886 \\
\hline 3. & .988 & 9.883 & 73.769 & & & & & & \\
\hline 4. & .983 & 9.831 & 83.599 & & & & & & \\
\hline 5. & .736 & 7.357 & 90.956 & & & & & & \\
\hline 6. & .428 & 4.283 & 95.239 & & & & & & \\
\hline 7. & .329 & 3.289 & 98.528 & & & & & & \\
\hline 8. & .090 & .903 & 99.431 & & & & & & \\
\hline 9. & .033 & .327 & 99.431 & & & & & & \\
\hline 10. & .024 & .242 & 100.000 & & & & & & \\
\hline
\end{tabular}

Source: Primary data

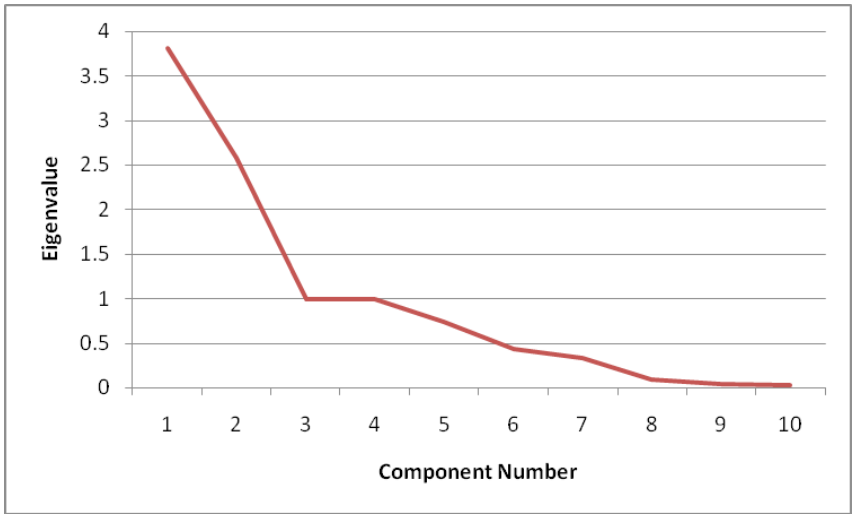

Figure 1. Screen plot.

Table 12 shows that the total variance is explained with rotation and Eigen values for factors 1 and 2 are 3.808 and 2.581. Percentage of variance for factors 1 and 2 are 38.076 and 25.810. It indicates that two factors were extracted from ten variables which have a cumulative percentage up to 63.886 per cent of the total variance i.e., 10 statements were reduced into 2 underlying factors.

Extraction Method: Principal Component Analysis

The screen plot in Figurel shows Eigen Values on Y axis and Components on $\mathrm{X}$ axis and the components which are with Eigen values above 1 are considered as the extracted factors.

\subsubsection{Determination of Factors based on Eigen Values}

The Rotated Component matrix in Table 13 shows the various statements which are selected for each factor extracted.

Extraction Method: Principal Component Analysis

Rotation Method : Variance Kaiser Normalisation

a) Rotation converged in 2 iteration 
Table 13. Rotated component matrix

\begin{tabular}{ccc} 
& \multicolumn{2}{c}{ Component } \\
& 1 & 2 \\
\hline VAR0001 & -.095 & -.290 \\
VAR0002 & .770 & .284 \\
VAR0003 & .562 & .494 \\
VAR0004 & .738 & .281 \\
VAR0005 & .048 &. $\mathbf{8 0 2}$ \\
VAR0006 & -.024 & .954 \\
VAR0007 & -.016 & .954 \\
VAR0008 & .768 & -.185 \\
VAR0009 & .833 & .085 \\
VAR0010 & .799 & .097 \\
\hline
\end{tabular}

Source: Primary data

The rotated component matrix shown in Table 13 is a VARIMAX procedure of factor rotation. Interpretation is facilitated identifying the variables that have large loading on the same factor. Hence those factors with high factor loading in each component i.e., values greater than 0.5 are selected. The selected factors are named separate relevantly.

Table 14 shows the rotated component matrix in which the extracted factors are assigned with a new naming by encapsulating related factors together.
Factor 1 shows 3.808 per cent of the variation. The extracted 'Improved electricity quality and reliability' (.770), 'Reduced insurance and risk related cost' (.562), 'Improved educational quality' (.738), 'Improved environmental and financial performance' (.768), 'Greater responsiveness to social environmental expectation' (.833) and 'Enhanced social, human and knowledge capital' (.799) are highly correlated with each other. These statements reflect the improved electricity quality and reliability, Reduced insurance and risk related cost, Improved educational quality, Improved environmental and financial performance, Greater responsiveness to social environmental expectation, Enhanced social, human and knowledge capital and these factors are therefore named as Improvement in Environmental Quality and Financial Performance.

Factor 2 shows 2.581 per cent of the variation. The extracted 'Reduced natural resources consumption' (.802), 'Reduced waste' (.954) and 'Reduced Pollutant emission' (.954) are highly correlated with each other. These statements reflect the reduced natural resources consumption, reduced waste, reduced pollutant emission and these factors are therefore named as Energy Conservation.

\section{Key Findings}

- The assessment of existing green initiative measures implemented among sample colleges based on ten parameters identified, very much confirm that all the sample colleges surge ahead in achieving clean and green environment for environmental sustainability.

Table 14. Naming of factors extracted

\begin{tabular}{ccc}
\hline Factors and \% Total Variance & Variables & Rotated Factor Loading \\
\hline I (3.808) & Improved electricity quality and reliability & .770 \\
$\begin{array}{c}\text { Improvement in } \\
\text { Financial Performance }\end{array}$ & Reduced insurance and risk related cost & .562 \\
& Improved educational quality & .738 \\
& Greater responsiveness to social environmental expectation & .833 \\
II (2.581) & Enhanced social, human and knowledge capital & .799 \\
& Reduced natural resources consumption \\
Energy Conservation & Reduced waste & .802 \\
& Reduced Pollutant emission \\
\hline
\end{tabular}


- Through the factor analysis 10 factors exposing the benefits of green practices reaped among sample colleges considered for the study were condensed into 2 factors named, first as Improvement in Environmental Quality and Financial Performance and the second factor as Energy Conservation. The first factor 'Improvement in Environmental Quality and Financial Performance' is the most beneficial factor accounting for 3.808 per cent of the variation, followed by 'Energy Conservation' accounting for 2.581 per cent of the variation.

\section{Suggestions}

- Sewage treatment plant should be installed in all higher education institutions for recycling waste water to achieve efficient resource utilisation.

- Higher education institutions should not bother about cost incurred at the initial stage of implementing green practices, because it gives long run advantages which help to save the environment.

- Activities regarding green measures should be planned well in advance and be implemented subsequently one by one to manage financial constraints.

\section{Conclusion}

Environment plays a vital role for healthy living. Earth is the only planet where life exists and it is our duty to protect the environment. However, there has been unprecedented growth in the awareness on the environment world over, during the past three decades. Further, the green initiative measures taken at higher education institutions to protect the environment have created awareness among the youth. This paper enlightens the outcome of green initiatives of higher education institutions of arts and science in Erode district and helps to identify the key factors that contribute to the sustainable development of the economy converged with the enhanced environmental protection.

\section{Acknowledgement}

I earnestly acknowledge the University Grants Commission (UGC), Southern Eastern Regional Office (SERO), Hyderabad for the financial assistance rendered to carry out this research.

\section{References}

1. Sharma AK. Impact of the development of science and technology on environment. Everyman's Science. 2013 Jun-Jul; 48(2):89-121.

2. Yasmin T. Saving for the future. Consumer Connect Initiative. The Economic Times; 2013 Dec 13 p. 7.

3. Maheswari A. Noopur.Modi@timesgroup.com. Go Green. Consumer Connect Initiative. The Economic Times; 2014 Sep 29. p. 17.

4. Cummings GA. Turning higher education green from the inside out: A qualitative study of four colleges and universities who "Made Green Happen" [PhD thesis]. Higher Education Management. University of Pennsylvania; 2010. p. 1-24. Available from: www.proquest.com.

5. D’Alimonte M. Green school initiatives: Saving money, resources and student health. Alternatives International Journal. 2012 Apr. Available from: www.alterinter.org

6. Shweta Aggarwal and Utkarsh Jaiswal. Environment Friendly Computing: Green Computing, International Journal of Environment Science. 2013 December; 4(2): 79-82.

7. Lin C-Y, Ho Y-H. Determinants of green practice infusion: A conceptual model. International Journal of Management. 2014 Feb; 4(2). ISSN: 2249-0558.

8. Vernekar SS, Venkatasubramanian K. Green initiatives in indian industry: A silhouette. Journal of Commerce and Management Thought. 2014 Jan; IV(4). ISSN 0975-623.

9. Williams B, Onsman A, Brown T. Exploratory factor analysis: A five step guide for novices. Journal of Emergency Primary Health Care (JEPHC). 2010; 8(3):1-13. Article 990399.

10. Hair J, Anderson RE, Tatham RL, Black WC. Multivariate data analysis. 4th ed. New Jersey: Prentice Hall Inc; 1995. p. 373.

11. Tabachnick BG, Fidell LS. Using multivariate statistics. Boston: Pearson Education Inc; 2007. p. 611. 